\title{
A tale of two civilizations in the era of Facebook and blockchain
}

\author{
Hernando de Soto
}

Accepted: 29 September 2017 / Published online: 6 November 2017

(C) The Author(s) 2017. This article is an open access publication

\begin{abstract}
Five billion people in the world do not have the kind of ledgers that provide the documented information that allows them to transfer, partition, and aggregate assets and talents in such a way that they can be scaled up, secure investment, guarantee credit, certify reputation, and capture abstract surplus value. The difficulty that most people have in making combinations is a major cause of global inequality and unnecessary poverty.
\end{abstract}

Keywords Entrepreneurship - Institutions · Poverty · Development $\cdot$ Property rights

JEL codes $\mathrm{L} 26 \cdot \mathrm{O} 10 \cdot \mathrm{O} 17 \cdot \mathrm{P} 14$

\section{Introduction}

My work illustrates that in many countries in the world, the poor have become a new class of entrepreneurs. It also aims to explain why and how the poor organizes themselves outside the law. It makes the case that social and political peace will not be possible until all of those who know that they are excluded feel they have a fair

This article is based on the author's presentation at the Global Award for Entrepreneurship Research ceremony in Stockholm, Sweden, May 15, 2017.

H. de Soto $(\square)$

Institute for Liberty and Democracy, P.O. Box 18-1420, Lima,

Peru

e-mail: mgago@ild.org.pe

e-mail: hds@ild.org.pe chance to achieve the standards of the West. My first book, The Other Path (de Soto 1989), was based on extensive research that my colleagues and I did in Peru and sets the scene for reform. ${ }^{1}$ It was also a landmark in the ILD's own development from a traditional "think tank" to the "think and acting" organization that we became in the 1990s, first in Peru then worldwide. Based on facts, numbers, and historically based analyses, The Other Path makes the following major points:

- Many Peruvians are emerging entrepreneurs working outside the legal system. Legally employed proletarians made up less than $4.8 \%$ of the Peruvian population at the time.

- My work illustrated that the real revolutionary class in Peru is made up of the micro, small, and mediumsized entrepreneurs who during the last half of the twentieth century began migrating from rural areas to towns and cities to work in the fragmented market economies of the informal or "extralegal" sectorwithout easy access to the mainstream legal system and the property and business rights essential to prosper.

- These extralegal entrepreneurs are hardly a small and marginal sector of Peruvian society. My and ILDs calculations showed that they, together with their extended families, constituted the majorityaround $60-80 \%$ of the nation's population. They constructed seven out of every ten buildings; they

\footnotetext{
${ }^{1}$ ILD (the Institute for Liberty and Democracy) is a Lima-based think tank that works with developing countries to implement property and business rights reforms.
} 
had built and owned 278 out of Lima's 331 markets; they operated $56 \%$ of all businesses of the nation; they retailed over $60 \%$ of all foodstuffs; and they operated $86 \%$ of all the busses. For some 40 years, these people have been trying to convert themselves into an entrepreneurial class resembling the selfreliant American settlers of the eighteenth and nineteenth centuries. Peru's extralegal entrepreneurs were not timid shoeshine boys who run for cover when they see the police. They are forceful pioneers.

- It is the same case in Egypt, where with my team we discovered that extralegal entrepreneurship were dominant in most developing economies. For example, we discovered after a few years of work in Egypt, that they cover over $82 \%$ of the Egypt's enterprises and $92 \%$ of real estate. That makes the informal economy Egypt's single biggest employer, providing jobs to 8.2 million people. It also controls $\$ 360$ billion worth of real estate assets, which is 54 times greater than the value of the Foreign Direct Investment in Egypt since Napoleon invaded two centuries ago, 6 times last year's World Bank total budget and 10 times the USAID and State Department allocation requested by President Trump for 2018.

- These entrepreneurs want to live under the rule of law. Even though they are forced to operate outside the Peruvian legal system, they have made their own rules, which I call "extralegal law." For them, the market economy and capital are not "bourgeois prejudices" or "culturally alienating concepts" but goals that they and their informal organizations strive to reach. I described how their spontaneously created rules do not reflect a feudal, tribal, or communist system, but rather a market economy.

- Most Peruvians do not lack property. On the contrary, our calculations showed that they own assets with a replacement value in excess of US\$80 billion-14 times greater than the value of foreign direct investment in Peru. Collectively, and unconsciously, Peru's entrepreneurial majority began a market and social revolution against economic poverty and legal oppression.

A main argument in the book is that the existing legal system in Peru at the time did not work in favor of the poor. Instead, it excluded them. Based on real case histories and simulations, the book demonstrated that in Peru, for example, it took a new entrepreneur 13 years to overcome the legal and administrative hurdles required to build a retail market for food that would help take vendors off the street; 21 years to obtain authorization to construct a legally titled building on wasteland; 26 months to get authorization to operate a new bus route, and nearly a year, working 6 hours a day, to gain the legal license to operate a sewing machine for commercial purposes.

In the face of such obstacles, new entrepreneurs hold their assets outside the law and therefore do not have access to the facilitative devices that a formal legal system should provide to help them organize and leverage resources. Because they have no secure property rights and cannot issue shares, they cannot capture investment. Because they have no patents or royalties, they cannot encourage or protect innovations. Because they do not have access to contracts and justice organized on a wide scale, they cannot develop long-term projects. Because they cannot legally burden their assets, they are unable to use their homes and businesses to guarantee credit. If European and American businessmen did not have access to the limited liability systems and insurance policies that the law allows, how many risks would they run? How much capital would they accumulate without legally created paper that can represent value? How many resources would they be able to pool without legally recognized business organizations that can issue shares? How often would Europeans or Americans choose bankruptcy and try to start all over again if the law did not allow them to convert their debts into shares?

Because the poor cannot hold assets or trade within the law, they cannot be part of the global economy either. How can you fill in a bill of lading if you do not have a legal address or an officially recognized business? How can you move an asset in the international market place if it is not fixed in a formal property system? Obviously you cannot, and that is why the excluded will not benefit very much from globalization. Moreover, can you understand what the poor feel when a foreign investor comes into their country with clear legal property rights that can be enforced both nationally and internationally, while they have none? Do you think they will sympathize with globalization, or do you think they will feel it is exclusive and unfair?

My conclusion about Peru was that the economic system oppressing most Peruvians is mercantilism. The Other Path demonstrates that democratic capitalism, as it is known in the West today, had not really been 
tried in Peru — or, for that matter, in most places outside the West. Mercantilism can be defined as the supply and demand for monopoly rights by means of laws, regulations, subsidies, taxes, and licenses. The fallout of these privileges creates a wall of legal barriers that exclude the poor. Mercantilism is a politicized and bureaucratized environment dominated by privileged redistributive combines that prevailed in Europe before and during the Industrial Revolution, before the rise of democratic capitalism.

Based on insights from the work reported in The Other Path, ILD started to design rules, procedures, and organizations to help the government listen to its own people. We not only found out where some of the major bottlenecks in the system were located, but we also learned to devise solutions, build institutions, and draft, promote, and then implement major legislation and reform projects. During that period, the ILD initiated some 400 major laws and regulations and managed one of the world's largest property-creation projects.

\section{The role of property}

My ILD colleagues and I realized that property is more than just ownership; it is the hidden architecture that organizes the market economy in every Western nation. Without a legal property system, efforts to create a sustainable market economy are doomed to fail, as I have argued at length in my other major book, The Mystery of Capital: Why Capitalism Triumphs in the West and Fails Everywhere Else (de Soto 2000).

The connection between the formal property system and the creation of wealth is something that the rich nations of the West take for granted. But this essential connection became clear to us only when we realized that in spite of owning houses and businesses, most Peruvians could not generate wealth because their assets were held outside the legal property system. And thus in numerous articles and pamphlets, posters and TV spots, the ILD argued that without property institutions and organizations, a modern market economy cannot work. Why? Because ownership cannot be certain, addresses cannot be systematically verified, assets cannot be described according to standard business practices, people cannot be made to pay their debts, authors of fraud and losses cannot be easily identified. As a result, buildings and land cannot be used to guarantee credit or contracts. Ownership of businesses cannot be divided and represented in shares that investors can buy. Without property law, capital itself is impossible to create because the instruments that store and transfer value, such as shares of corporate stock, patent rights, promissory notes, bills of exchange, and bonds, are all determined by the architecture of legal relationships with which a property system is built.

Gaining this insight not from books but by talking to the poor and observing how they lived, we were able to design and implement a legal property system around the objective interests of the poor themselves. The legal devices we created worked because we made sure that they were compatible with the principles that the poor already used in the extralegal economy. More importantly, by relying on the poor for rule making and support, the Peruvian government could now push for reform, but not in the name of a foreign ideology, philosophers the people had never heard of, or the dictates of an international financial institution. They could institute major reforms in the name of the nation's poor. This allowed us to convert (at least for a while) the transition to capitalism and liberal democracy into what it should always be - a truly humanist cause, a genuine war against exclusion, rooted in the best interests of the nation. This provided the Peruvian head of state with a formidable argument: "The majority of the nation's population is cut off from the official market economy and access to capital as starkly as apartheid once separated white and black South Africans and we are going to correct that."

ILD undertook several measures to resolve issues of the Peruvian legal system. For example, ILD put into place all the legislation and mechanisms required to bring into the law most extralegal real estate and businesses. On the real estate side, we brought down the administrative time needed to record the property of the poor from more than a dozen years to 1 month, and cut the costs by $99 \%$. By 1995, such reforms had brought into the legal system some 300,000 owners whose property on average at least doubled in value. Twenty-five credit institutions began giving loans to these now legal owners. By 2000, some 1.2 million buildings on urban land had entered the legal system, about $75 \%$ of the extralegal market.

On the business side, we cut the cost of entering business from some 300 days down to 1 . We also put registration offices in the right places and made the government bureaucracy more user-friendly for small entrepreneurs. By 1994, over 270,000 formerly 
extralegal entrepreneurs had entered the legal economy, creating over half a million new jobs and increasing tax revenues by US $\$ 1.2$ billion.

\section{The problem of the legal system}

ILD's goal was to figure out ways of bringing the majority of Peruvians into a legal system that had traditionally shut them out and thus stunted the nation's economic development.

What I came to understand was that a massive social and economic revolution was underway in the developing world rivaling the Industrial Revolution in the West that gave rise to market capitalism. In the last 40 years, some 4 billion people, who had been living in the hinterlands of developing countries and former Soviet nations, have abandoned their traditional way of life. They are moving away from small, isolated communities towards a larger and more global division of labor in the expanding markets that both Adam Smith and Karl Marx had seen emerging in the West 200 years ago, and that are now struggling to emerge outside the West.

These people clustering around big towns and migrating by the hundreds of millions to larger cities are the newest players in the global scene. Over the 4 decades before I wrote The Other Path, for example, the population of Peru's capital city of Lima increased sixfold; Port-au-Prince, Haiti's capital, increased at least 15 times during the same period; the population of Ecuador's Guayaquil increased 11 times. The underground economies in Russia and the Ukraine accounted for 50\% of GDP; the black market in Georgia generated a whopping $62 \%$. The International Labor Organization reported that since 1990, $85 \%$ of all new jobs in Latin America and the Caribbean have been created in the extralegal sector. In Zambia, only $10 \%$ of the workforce was legally employed. From Peru to the Philippines, these extralegal workers and entrepreneurs were improving their lives. They read, traveled, and had radios and televisions. As a result, they know that the Westernized elites of their nations live well, and they too aspire to that good life.

The economic potential is clearly there. Although the new migrants of the developing and post-communist world now live in shantytowns and are horribly poor by Western standards, they are not without assets. The ILD's work over the past 20 years has revealed the extraordinary entrepreneurial potential of the people of the Third World. According to our estimates, over the 40 years before I wrote The Other Path, these people created more than US\$10 trillion of wealth, a value 90 times greater than all bilateral foreign aid and 40 times larger than international development loans received by undeveloped nations, and a value larger than the size of the world's 20 largest stock markets.

The difference between today's industrial revolution and the one that began in the West more than 200 years ago is that this new revolution is roaring ahead much faster and transforming the lives of many more people. Britain supported just 8 million people when it began its 250-year progression from the farm to the laptop computer. Indonesia is making that same journey in only 4 decades - with a population of more than 200 million. Is it any wonder that Indonesia's institutions have been slow to adapt? But adapt they must. A tide of humanity has moved from isolated communities and households to participate in ever-widening circles of economic and intellectual exchange. It is this tide that has transformed Jakarta, Mexico City, São Paolo, Nairobi, Bombay, Shanghai, and Manila into megacities of 10, 20, 30 million and overwhelmed their political and legal institutions.

Instead of helping them, the law excludes them. It is this legal lag that produces a pervasive sense of alienation — of being a class apart. Some have argued that the appearance of small enclaves of prosperous economic sectors in the midst of large undeveloped or informal sectors marks the dawn of an uneven but nevertheless inevitable and easy transition to capitalist systems. I do not buy this. The existence of prosperous enclaves in a sea of poverty conceals an abysmal retardation in many nations' capacities to create channels of communication with these excluded people - the majority of their citizens - and to make available the underpinnings of the rule of law by providing them with formal property rights.

\section{Two civilizations}

Human communities transformed themselves into civilizations when they titled and recorded the indefinite property rights they respected in rule-bound ledgers, thus providing entrepreneurs the knowledge and means to securely combine rights to inconsequential single assets into more valuable wholes. 
Over time, the communities that gave special attention to ledgers increased their knowledge incrementally, as the process of collecting, categorizing, validating, and recording obliged them to understand which rights were important for their welfare and worth remembering. They are the people who were able to combine talents and assets so as to create surplus value ex nihilo.

The result today is two unequal civilizations:

- The combining civilization has 2 billion members whose ledgers connect them to law that not only awards them the original right to own assets but also some 20 additional rights to join them into more complex and valuable combinations - from cars and computers to sophisticated infrastructure projects.

These additional rights include those of pledging title to assets against investment and credit, crossing sovereign borders to scale up their markets and appropriating the surplus value generated by combinations.

- The other is the lagging civilization of 5 billion members whose ledgers are so disconnected from the laws that award and enforce the additional rights that they cannot easily combine, leverage or enforce whatever rights they are entitled to beyond narrow sovereign boundaries and thus cannot scale up to generate surplus value.

The consequences of most of the world not having the property rights needed to combine are, to a great extent, terrorism, conflicts over the environment, migration, the lack of public services, and even revolution.

Peru and other countries in the developing world encounter several problems. Below I list what I consider to be the most important problems that I have come in contact with in my work around the world.

\subsection{Lack of public services}

Not having rights to combine and pledge assets means that many members of the lagging civilization cannot use their property documents to act as credentials for receiving public services. For example, a house with full rights can function not only as a shelter but can also lead a parallel life as a locus for identifying residents for commercial, judicial, and civic purposes; and as a liable terminal for receiving public utility services, such as energy, water, sewage, telephone, or cable services.
4.2 Racketeers and terrorist groups

The most frustrated among the 5 billion people without property rights and their economic benefits have tacitly concluded, rightly, wrongly, and in a state of learned helplessness, that Westerners will continue to appropriate their resources and probably at their expense. Their response has been to surrender the protection of their property to terrorist or criminal groups. Why? Because enforcing sovereign boundaries and property rights recorded in disconnected ledgers is the business of terrorist groups everywhere, whether Al Qaeda and ISIS in Central Asia and the Middle East and North Africa (MENA) or the Shining Path and FARC in Latin America.

In fact, offering protection of local property rights is a tried and true strategy used by insurgency groups to gain the respect, shelter, taxes, and recruits from alienated populations, which will in turn aid them in conquering the sovereign right to govern the very territory these people inhabit.

\subsection{Environmental wars}

Poor populations living in territories rich in natural resources too often blame all their woes resulting from environmental damage on extractive industries blessed by government concessions. According to ILD research, however, local communities are not altogether blameless. Fearing their inability to match the political and legal power of large companies, local activists proceed to challenge the official legal system by issuing their own titles. Legal conflicts - and illegal violenceensue.

Ideally, of course, there should only be one standard title and ledger system capable of identifying those who hold sovereign and property rights over damaged territory, which would single out and reward those who spot the damage.

\subsection{Massive migration}

People who feel dispossessed and with little of value to lose are more willing to emigrate to combining civilizations - fortified by the hope that in their new country the rule of law will award legal rights to whatever property their ambition, talent, and hard work helps them obtain. 


\subsection{Revolutions}

People who are arbitrarily — and violently dispossessedcan take to the streets and start revolutions that topple governments; they will even commit suicide in protest. This might strike most Westerners as an extreme response, but it was exactly what hundreds of people in the MENA region did in 2010-2011, lighting themselves on fire to protest against what they complained was the "expropriation" of their assets, sparking "the Arab Spring," which in turn unleashed sectarian hatred, terrorism, and civil war, forcing millions more to migrate to the West.

\section{Methods learned}

In my experience, giving property rights might help end violence, provided it is a bottom up process, i.e., that rights are given in terms of the social contract which underpins the disconnected ledgers. The authorities managing the local ledgers have to be engaged directly with their constituencies addressed through crowd sourcing media.

In the uphill process of figuring out how to give appropriate property rights to those that do not have them, we learnt through trial and error how to think and act in a world split into two civilizations. I am not saying that these methods are applicable in all circumstances nor that they should meet everyone's approval but they are the ones that worked for us.

\subsection{Close your books and open your eyes}

Do not rely on existing conceptual frameworks that explain existing legal property rights law to organize your thoughts: it is clear that two thirds of the world has yet to find a way of fitting in it. Instead, build a conceptual framework that helps you angle, sequence and formulate questions contrived to make those who are part of a lagging civilization voluntarily provide you with the direct knowledge that is needed to address and solve that problem as well as a different perspective on what the books say.

5.2 Measure the time it takes for property legislation to reach the people it aims to help

Any good jurist in the lagging civilization is likely to confirm that all citizens, poor as well as rich, have the same property rights - legally. It is encoded worldwide, starting with the Universal Declaration of Human Rights, numerous international conventions, and ending with the constitutions and relevant mainstream laws of nearly all countries.

The history of the eighteenth and nineteenth century Industrial Revolutions in the USA and Europe demonstrates that it can take a century or two for property rights awarded at the commanding heights of law to navigate across what I have come to call the "legal lag," a turbulent stream of outdated laws and unnecessarily complex administrative procedures, before a right to property is spelled out in a manner that allows disconnected ledgers to be incorporated into the legal system.

Same thing today: Much of the legislation that enables the widespread exercise of property rights that was initiated in the last quarter of a century or so, after the fall of communism, has not found its way into the lagging civilization.

5.3 Do not restrict the quest for knowledge about how to use property rights as a tool for problem solving to the field of property law

In my experience, researching the legal systems of developing countries, many crucial property rights are not contained in property law. If your mission is to help boost the poor out of poverty by giving them the legal tools to combine their assets into more valuable wholes, it is important to understand that property rights are about more than property law.

Others disagree, but if I win the debate, it would mean that one of the reasons that titling programs are failing is because they do not award the property rights needed to create combined assets, create surplus value and solve violent problems.

Not generally available in the lagging civilization for making combinations possible are the crucial rights to:

1. Partition assets individually or collectively outside family, communal, or political hierarchies so they can be combined to fetch surplus value.

2. Partition assets so they may be used to pay debts that are smaller than the value of a business so as not to have to liquidate the whole business.

3. Use assets to guarantee a credit.

4. Divide assets into shares. 
5. Pledge shares against investment.

6. Guarantee perpetual succession.

7. Guarantee limited liability.

8. Partner or employ with people outside a political chain of command.

9. Constitute management hierarchies separate from family and political associations.

10. Raise capital inviting new partners.

11. Use assets as credentials for commercial, judicial and civic purposes.

12. Use a location as liable terminals for receiving public utility services, such as energy, water, sewage, telephone, or cable services.

13. Provide location information so authorities can skip trace criminal suspects.

14. Locate neighbors who damage the environment and make them accountable.

15. Own brands to capitalize reputation.

16. Be respected outside local boundaries.

17. Capture and transfer the surplus value of a combination.

18. Obtain global identity.

19. Securitize value to raise finance.

20. Feel safe enough for spouse to get a job and children to go to school instead of guarding their home.

21. Protect not only the house but also the business assets inside the house in case of eminent domain.

5.4 Do not start by examining the legal codes ruling property rights

Though codes contain a good deal of the information needed, you can only detect which codesand which part of the codes - are relevant to the quest using indicators collected from records in the lagging civilization.

The crucial knowledge about what rights are missing and which are the norms that cause the lags will be hard to extract from wading through the legal texts of the combining civilization. In Peru, for example, the central government produces roughly 106 laws and regulations per day, which adds up to 30,000 per year-more than half a million rules since communism collapsed, and Peru began to modernize. Learning anything from the laws on the books might even be more difficult than the proverbial search for a needle in a haystack.
5.5 Do not expect obtaining the necessary knowledge by examining the titles that represent rights in the lagging civilization

Unless your passion is anthropology, semiotics, or ontology, spending time examining the titles that represent claims to property in the lagging civilization will probably generate minor evidence of real rights and lags. Titles are discrete, dispersed, and not always written on paper.

5.6 Focus on the ledgers of the lagging civilization, the stewards who administer them and those who enforce the rules that bind them all. That is where the knowledge trail begins

Ledgers are more than a laundry list of what people own; they are, in fact, the initial point of entry into knowledge. It stands to reason: Ledgers are the result of a memory-based process, and what we know is only what we can remember.

Generally, ledgers are the most reliable source of knowledge because, in one way or another, they store the documents, the evidence and the testimonials not only of what one person thinks is true but what everyone in a given society believes is right. They are the written reflection of the "social contract" between members of a society as to how they relate to each other regarding the control, transfer, and enforcement of their property rights. In many cases, the social contract has also established what most people believe their sovereign rights to be, since they provide how they can be protected from the wealth and power of outsiders.

Two important facts about today's disconnected ledgers:

1. It is at the ledger level that rights are established, complied with, and enforced. That is where the reputations of their constituencies are made. Therefore, though most of the people in a lagging civilization would love to have combining rights, they will reject any entitlement that weakens the local consensus defending their existing rights, unless it is demonstrated that the obstacles causing the legal lag have been removed.

2. The knowledge required to identify the legal gaps that impede people from accessing the 21 combining rights that worldwide legislation establishes is also found at the ledger level. 
5.7 To address the disconnected ledgers, they have to be located, the authorities administering them identified, and then engaged directly

Even if disconnected ledgers look like an anarchic reality where things are difficult to find, we have found that these ledgers all fall neatly in 11 categories just about everywhere in the world. They are also easy to locate - if you follow the following protocols that the ILD has developed:

Six types of ledgers managed by legitimate grassroots or autonomous organizations-independently from the central government:

- Urban lodging, industrial and street settlements;

- Rural collectives;

- Extractive industry settlements;

- Infrastructure project settlements;

- Areas receiving small business financial services;

- Areas categorized by Government as smuggling and drug trafficking territory.

Five types of ledgers created on the basis of international agreements:

- International Treaties including Free Trade Agreements and Bilateral Investment Treaties;

- Ledgers resulting from international contract adherence;

- Ledgers drawn up by law firms for principals to sell securities;

- Ledgers resulting from the application of international organization guidelines;

- Ledgers resulting from the application of Ius Cogens.

5.8 Invite the ledger administrators to a meeting or put an ad in the newspaper, alerting them that you want to talk about the 21 property rights they do not have

In my experience, if you invite them, they will come4,000 to 15,000 people at a time. And then, let the knowledge gathering begin.

5.9 The overwhelming majority of people in the lagging civilization want to catch up and combine

The problem is that the process of awarding people rights is dreadfully slow. But during the past 2 years, we have found out that you can speed up the processand reach millions - by automatizing communications through social media.

Recently, a group of small entrepreneurs in remote, rural areas of Peru, mostly farmers and some still armed, appealed to me to help them improve their situation and the property rights they received 2 decades ago as part of the reforms ILD had helped to government implement in our fight against the Shining Path. I agreed to meet with them — and they showed up in force: 2,000, armed with guns and cell phones. Two months later, I sent out a request via Facebook to continue our meetings, to my amazement more than 2.4 million people responded.

The same thing happened when I decided to continue a personal meeting I had with 4,000 small mining entrepreneurs via Facebook - and reached more than 2 million people.

5.10 Devising and automated system that can substitute titles for rifles, rapidly and efficiently

About 2 years ago, I reached the painful conclusion that the methods we had developed to bring poor majorities into the legal systems of their countries did not deliver results quickly enough. Those CEOs, Heads of State, or humanists who are interested in connecting the two civilizations for business, governance or peacemaking purposes rarely have a mandate long enough for them to wait the years it was taking us to get massive results.

However, a couple of years ago, I met some very smart people very knowledgeable in ITC. The way they put it is that if I began exploring the venues offered by ITC and specially multiple distributed ledger systems, I may be able to lay the foundations of a digital system that could locate informal asset owners. In the course of continuous conversations and trading comments in conferences, many people informed me of the tools available in rapidly involving information technology that could help me find a way to shortcut the legal lag so that I could locate on a massive level the disconnected ledgers where most people of the world listed their property rights. I thus proceeded to devise ways in which my artisanal process to locate disconnected ledgers, identify their leaders, extract information and determine where their deontic powers to create ownership derived from so that they could be digitalized and plugged them into mainstream legal systems on a large scale.

Thanks to the encouragement and the patient coaching on digitalization received from various friends (notably Wences Casares, Duncan Macdonald, Alfonso 
Navarro, Nandan Nilekani, Antonio Ognio, Pierre Omidyar, Cyril Pavillard, Peter Rabley, Ignacio Soto, Bill Tai, Danny Yang and the steady support of my two colleagues Gustavo Marini and Manuel Mayorga to filter and organize the information obtained so that it could fit in my un-automated skull), I have now developed 13 computer-friendly methodologies and - if I find the right associates - am only a few months away from being able to digitally connect the lagging with the combining civilizations.

On the basis of our experience, we now believe that this new process can help locate most disconnected ledgers in any country by obtaining online information about them through four types of organizations covering 50 economic sectors. Through that pipeline, we expect to identify most ledger leaders; and, with their help, collect, categorize, and standardize the basic information about their ledgers and rights in a way that it can be translated into controlled vocabularies, which can be processed by computers.

All that information would then be recorded in a digital registry. And then, in a second pass, using fill in questionnaire forms guided by 34 indicators, identify what rights are missing and where the obstacles to obtaining them are.

With that information sorted out - and on the basis of machine reading systems guided by other indicatorswe can identify where the legal rights to combine are hidden within the legal maze. We can then build digital tunnels and bridges to shortcut the legal lag. Even before reforms are made, the information obtained can produce quick results via distributed ledger systems and smart contracts to solve conflicts and connect governments and large businesses to the lagging ledgers within the context of a law that both sides of the divide can trust.

5.11 Use history to remind those Westerners, who have a hard time believing all of the above, that their ancestors were once there and that change is possible

To this end, I have made an effort to inscribe our strategy into the history of the Industrial Revolution in the West. My suspicion is that a key ingredient to organizing the standard ledger knowledge that entrepreneurs require to make combinations and gauge risks came about more as a result of satisfying their needs throughout the ongoing Industrial Revolution than through reflection. The basis for this statement is that I was impressed by how little credit was given to all the property knowledge gathering, selecting and standardization that the dramatic process of industrialization brought about.

In my reading of history, the founding fathers of market thinking agreed that the shortcomings of their discipline had a lot to do failing to understand how people come to trust others in order to do business. For many of them, economics did little to explain how businesses marshal the knowledge they need to trust each other, identify creditworthiness, divide labor productively among themselves and make efficient decisions. Karl Marx wondered where one could find the "essential links and relations" that allow humans to know each other and cooperate on a large scale; while Friedrich von Hayek dedicated a whole book to making the case that the human mind does not have the sensory attributes to know economic reality directly and to access the existing knowledge dispersed throughout the world.

Many economists, sociologists and psychologists either assumed the problem away or borrowed from philosophy the logical tools that elucidate collective understanding: Adam Smith's "invisible hand," Hayek's "catallaxy," Foucault's “episteme," Popper's "world three" and Jung's "knowledge rhizome" boosted the issue of knowledge into the realm of metaphysics - thus tip toeing around the directed knowledge stored in ledgers on the basis of sophisticated and tested criteria, which comes about by revealing the relationships that make up a consensus.

Yet, stretched over five bumpy generations, it was ledger building that picked up, structured and transmitted much of the ripe knowledge, we need to trust each other and make combining decisions. Large-scale ledgers arose to prevent the collapse of the industrial and commercial revolution. At that time, the growing force of expanding markets was destroying traditional, small-scale forms of production - such as feudalism, patrimonialism, and tribalism - and putting many people out of work. The result was a huge rift between the social order and the expanding market, as angry and alienated people unable to be quickly integrated into the new economy took to the streets, unsettling and toppling governments.

Enterprise could not pick up the jobless and poor because most forms of reliable economic knowledge were organized on a small scale, too small to allow entrepreneurs and financiers to trust and divide labor on a large scale. So, one way or another, it was crucial to organize knowledge on a large scale so that all players in every nook and cranny of the West's widening markets, 
in Charles Coquelin's words, "could pick up the thousands of filaments that businesses are creating between themselves, and thereby socialize and recombine production in a mobile fashion...so as to readapt the social intelligence of society."

The result was the invention of large-scale ledgers or what I have called "public memory systems" to record and classify - in rule-bound and publicly accessible registries, titles, balance sheets, and statements of account - all the knowledge available relevant to the economic situation of people and the assets they controlled, whether they were intangible (stocks, commercial paper, deeds, contracts, patents, companies, and promissory notes), or tangible (land, buildings, boats, machines, animals, and books). Knowing who owned and owed what and where and under which circumstances made it possible for investors to infer value and take a risk.

What do ledgers or memory systems have to do with knowledge? Plenty, for two reasons:

The first is that knowledge is essentially a memorybased process, which involves selecting, categorizing and storing the knowledge we need. Knowledge increases incrementally forcing us to understand and validate each additional input obtained so as to decide which one is important to our welfare and worth remembering, how it should be written up and packaged, in what context it should be described and how it should be stored so as to be easily retrieved and combined.

The second reason is that ledgers created facts by aggregating bits of information into larger wholes that are easy to perceive and test for truth. As the British philosopher Bertrand Russell would have put it, the world, out there, is made of minuscule atomic facts that he called "little patches of color," which, when combined, could take the form of a picture... something that is easier for the eye to see and the mind to understand.

Significantly, the definition of "fact" evolved along with public memory systems: 150 years ago, "fact" described an occurrence, a deed; today in business, "fact" means a precise, rule bound, standardized statement that faithfully signifies a particular set of relationships.

Sure, facts are not only created by ledgers; and, of course, knowledge originates and can be stored in more places than ledgers. But my point is that complex combinations, which require verified and authenticated information, are hard to produce without the facts produced by ledgers.

\subsection{Contextualize}

The dramas of Oliver Twist, Jean Valjean, and Mohamed Bouazizi can only be explained in the context of the times they lived in. I realize how dangerous it is for a Latin American to seek so much support from the history of the Industrial Revolution in Europe and the USA to make my case for property recordation. I know how keen Europeans are about history; and that, no matter how rational and coldeyed they might be, familiar historical allusions are likely to ignite deep-rooted emotions. Reading Fernand Braudel on the rise of property, you can see that overall he admires the process. Reading Thomas Piketty, you can see that everything associated with property is a horror story that he links to the hardships of Jean Valjean, as drawn by Victor Hugo in Les Miserables, and the suffering of Oliver Twist drawn by Charles Dickens.

But the reader must understand that regardless of the tragedies and glories, the rights and wrongs, of the Industrial Revolution, I am using Western history to make the case that some of the best inventions in the world do not arise spontaneously from one particular brain (or many brains), but are a response to some dramatic challenge.

Those dramatic challenges are now popping up all over the world; and because the West is not associating them with property rights issues, it is not responding to them correctly. A case in point is the Arab Spring, sparked in December 2010 by the selfimmolation of Mohamed Bouazizi, a Tunisian entrepreneur, protesting the arbitrary expropriation of his merchandise.

Bouazizi's suicide and the news that it was a violation of his property rights that caused such a desperate act of protest, sent dozens of millions of people into the streets who in a few short months toppled four authoritarian governments. No wonder: I have estimated that more than 200 million people throughout the Middle East and North Africa depend on income from operating businesses and living in territory protected by the vulnerable disconnected ledgers of the lagging civilization.

My researchers located ledgers in different parts of MENA and found that Mohamed Bouazizi's desperate 
protest was not unique. We discovered that at least 63 more MENA entrepreneurs, men and women, in Tunisia and Algeria, Egypt, Morocco, Saudi Arabia, Syria, and Yemen, had followed Bouazizi's example within 60 days of his death - the critical period during which governments were toppled.

Of the 64 self-immolators, 37 survived, and over a couple of years we interviewed them on film. They were all entrepreneurs and none of them made a political or religious statement. The principal reason that these selfimmolators gave for their acts was "expropriation," arbitrary seizure of property weakly protected by a disconnected ledger.

A common view of Bouazizi's death is that he killed himself because authorities confiscated one of his fruit carts containing assets worth $\$ 225$. Examining the ledgers, we found that it was more than that. What he actually lost were nine property rights to:

1. Capture new investment by issuing shares

2. Raise capital by bringing in new partners

3. Raise financing by issuing bills and notes

4. Expand markets beyond family and neighborhood

5. Pool skills and resources by collaborating within an enterprise with non-family members

6. Ensure throughout time the survival of reputation, goodwill, brands, and other such intangible values by legally documenting them

7. Protect personal, family or communal assets by limiting liability

8. Use reputation and property as information and collateral for credit

9. Enforce public and private commitments over the long term

We published our results, and the Arab press caught on quickly. Our research generated nearly 200 newspapers and magazines headlines across the MENA region-but no headlines in the West.

\section{By way of conclusion}

Why was it so difficult to recognize that the Arab Spring - and all the other revolutions in the lagging civilization - are motivated by the desire of millions of ordinary people operating outside the law to protect and combine assets and thus join the Industrial Revolution? One difficulty could be that some Westerners bundle property rights with the notion of privilege and have difficulties in treating them separately. Whatever the case, we are now divided into two distant civilizations, the complex and the simple, which means we are still a long way from becoming a global village.

Another difficulty is that the difficulty of visualizing the institutions that hold together the societies of the lagging civilization. These institutions are housed in thousands of disconnected ledgers and hidden in millions of pieces of legislation, statutes, and regulations. I now believe that can be remedied by editing that information so that it fits on digital screens, aggregated and linked to the current affairs that concern us - and thus clearly seen.

Reading over what I have just written, I believe more and more that rule bound property ledgers are an extraordinary creation of mankind. Unlike tigers and wolves, who bare their teeth to protect their territory, we humans, much weaker animals physically, have used our minds to create a legal environment where on the basis of consensuses materialized in ledgers; we can protect our territories with rights instead of fights.

In the process of structuring a legal system to settle claims, we have inadvertently created a system that has taken on a life of its own, providing us the knowledge we need to improve the lives of poor entrepreneurs around the world. As Alexis de Tocqueville once wrote: "Knowledge of how to combine is the mother of all other forms of knowledge."

Open Access This article is distributed under the terms of the Creative Commons Attribution 4.0 International License (http:// creativecommons.org/licenses/by/4.0/), which permits unrestricted use, distribution, and reproduction in any medium, provided you give appropriate credit to the original author(s) and the source, provide a link to the Creative Commons license, and indicate if changes were made.

\section{References}

de Soto, H. (1989). The other path: the invisible revolution in the Third World. New York: HarperCollins.

de Soto, H. (2000). The mystery of capital: why capitalism triumphs in the West and fails everywhere else. New York: Basic Books. 